\title{
PERSEBARAN SARANA DAN PRASARANA PERPUSTAKAAN SEKOLAH DASAR BERBASIS SISTEM INFORMASI GEOGRAFIS
}

\author{
Dhi Bramasta \\ Dedy Irawan
}

\author{
Program Studi Pendidikan Guru Sekolah Dasar \\ Universitas Muhammadiyah Purwokerto
}

\begin{abstract}
The aim of this research is to know the distribution of elementary school in Baturraden sub-district of Banyumas Regency and to know the condition of library and facilities of elementary school library in Baturraden Sub-district of Banyumas Regency. The research was conducted in Baturraden Sub-district of Banyumas Regency. The subjects of the study are primary school and the manager of elementary school library. This research is a qualitative descriptive research with spatial approach which is one approach in geography. Data collection techniques with observation, interview and documentation. Data analysis uses interactive analysis which includes reduction, display, verification and GIS. The results showed that the primary school distribution of Baturraden sub-district is clustered with distribution pattern following path or accessibility path. The number of books and equipment in the library has not been in accordance with the subjects and the number of students in the school, so that the condition of the facilities and infrastructure of elementary school library in Baturraden sub-district has not complied with the standard set by the government.
\end{abstract}

Keywords: facilities and infrastructure, primary school library, geographic information system

\begin{abstract}
Abstrak
Penelitian bertujuan untuk mengetahui persebaran sekolah dasar di Kecamatan Baturraden Kabupaten Banyumas dan mengetahui kondisi sarana dan prasarana perpustakaan sekolah dasar di Kecamatan Baturraden Kabupaten Banyumas. Penelitian dilaksanakan di Kecamatan Baturraden Kabupaten Banyumas. Subjek penelitian yaitu sekolah dasar beserta pengelola perpustakaan sekolah dasar. Penelitian ini merupakan penelitian deskriptif kualitatif dengan pendekatan keruangan yang merupakan salah
\end{abstract}


satu pendekatan dalam geografi. Teknik pengumpulan data dengan observasi, wawancara dan dokumentasi. Analisis data menggunakan analisis interaktif yang meliputi reduksi, display, verifikasi dan SIG. Hasil penelitian menunjukkan persebaran sekolah dasar Kecamatan Baturraden adalah clustered/ mengelompok dengan pola persebaran mengikuti jalan atau jalur aksesibilitas. Jumlah buku dan peralatan yang ada di perpustakaan belum sesuai dengan mata pelajaran dan jumlah siswa yang ada di sekolah, sehingga kondisi sarana dan prasarana perpustakaan sekolah dasar di kecamatan Baturraden belum sesuai dengan standar yang ditetapkan oleh pemerintah yang tertuang dalam Peraturan Menteri Pendidikan Nasional Nomor 24 Tahun 2007 tanggal 28 Juni 2007 tentang Standar Sarana Prasarana Sekolah/Madrasah Pendidikan Umum.

Katakunci : sarana dan prasarana,perpustakaan sekolah dasar, sistem informasi geografis

\section{PENDAHULUAN}

Pendidikan merupakan kebutuhan dasar manusia yang dibutuhkan untuk menjalani kehidupannya. Melalui pendidikan seseorang dapat meraih citacitanya. Melalui ilmu pengetahuan yang dimilikinya manusia mampu untuk menjadi apa yang diinginkan serta mampu hidup dalam masyarakat. Terlebih pendidikan di sekolah dasar yang merupakan faktor paling mendasar bagi pengetahuan yang didapatkan siswa yang merupakan modal di dalam melanjutkannya ke jenjang pendidikan yang berikutnya. Hal tersebut harus didukung oleh segala sesuatu yang mampu menunjang pelaksanaan proses pembelajaran dengan baik.

Agar pembangunan pendidikan dapat berkontribusi terhadap peningkatan kualitas sumber daya manusia, terdapat tiga syarat utama yang harus diperhatikan yaitu : (1) sarana gedung, (2) buku yang memadai dan berkualitas serta (3) guru dan tenaga kependidikkan yang profesional (Mulyasa, $2005: 3)$.

Dengan demikian ketersediaan sarana dan prasarana serta fasilitas sekolah mutlak untuk dipenuhi. Ketersediaan sarana dan prasarana serta 
fasilitas sekolah tersebut tentunya harus sesuai dengan kebutuhan sekolah dan disesuaikan dengan standar yang telah ditetapkan oleh pemerintah. Termasuk di dalamnya adalah sarana dan prasarana perpustakaan sekolah, dalam hal ini jika sarana dan prasarana perpustakaan sekolah memadai dan mampu memenuhi kebutuhan peserta didik dan sesuai dengan jumlah peserta didik yang ada, maka secara kuantitas dan kualitas sekolah serta peserta didiknya akan meningkat. Karena peserta didik memiliki wadah untuk mengembangkan ilmu pengetahuannya dengan segala sarana dan prasarana perpustakaan yang ada.

Begitu juga sebaliknya jika sarana dan prasarana perpustakaan sekolah kurang atau tidak memadai, kurang bisa memenuhi kebutuhan dan jumlah peserta didik yang ada, maka secara tidak langsung akan berpengaruh terhadap kuantitas dan kualitas sekolah serta peserta didiknya. Peserta didik kurang bisa mengembangkan ilmu pengetahuannya karena tidak memiliki wadah atau sarana untuk mengembangkannya. Namun kenyataannya sarana dan prasarana perpustakaan sekolah dasar sekarang ini masih banyak sekolah dasar dengan kondisi yang kurang sesuai dan kurang mampu untuk memenuhi kebutuhan dan jumlah peserta didik yang ada. Banyak hal yang menyebabkan hal tersebut terjadi, misalnya minimnya dana, pengelolaan dana sekolah baik dana bantuan pemerintah atau sumber dana yang lain dikelola dengan skala prioritas, sehingga dana yang seharusnya untuk memenuhi kebutuhan sarana dan prasarana perpustakaan bisa dialihkan ke hal yang lain karena hal lain tersebut lebih memiliki skala yang harus diselesaikan terlebih dahulu dibandingkan dengan sarana dan prasarana perpustakaan, bantuan pengadaan buku dari pemerintah juga dirasakan masih kurang bisa memenuhi kebutuhan perpustakaan sekolah. 
Dhi Bramasta dan Dedy Irawan : Persebaran Sarana dan Prasarana Perpustakaan Sekolah Dasar Berbasis Sistem Informasi Geografis

Letak atau lokasi sekolah yang jauh dari pusat penyedia berbagai fasilitas akan menghambat sekolah dalam proses pengembangan. Kemudahan sekolah untuk dijangkau dan kemudahan sekolah untuk menjangkau tempat dimana sekolah bisa mendapatkan berbagai keperluan sarana dan prasarana atau fasilitas untuk memenuhi kebutuhan perpustakaannya juga memberikan kendala dalam pengembangan sekolah. Fenomena distribusi sekolah yang jauh dari pusat kota atau jauh dari tempat dimana sekolah bisa mendapatkan berbagai kebutuhan sarana dan prasarana atau fasilitas sekolah serta didukung secara aksesibilitas letak sekolah yang sulit untuk dijangkau memberikan dampak yang kurang baik terhadap ketersediaan sarana dan prasarana perpustakaan sekolah. Letak sekolah yang memiliki aksesibilitas baik mudah untuk dijangkau dan dekat dengan pusat dimana bisa mendapat berbagai keperluan sekolah maka secara otomatis perkembangan sekolah tersebut akan lebih baik.

Mengacu pada hal-hal di atas penting mengetahui distribusi atau persebaran Sekolah Dasar tersebut. Pemetaan melalui analisis spasial dengan SIG (Sistem Informasi Geografis) memberikan informasi yang dapat memberikan informasi pola distribusi Sekolah Dasar dan mudah tidaknya sekolah tersebut untuk dijangkau ataupun menjangkau tempat lain di dalam proses pemenuhan kebutuhan sarana dan prasarana sekolah, sehingga bisa dijadikan dasar dalam perencanaan, pengawasan pembangunan, penataan ruang serta pengambilan kebijakan yang akan dilakukan.

Sebagai salah satu wilayah administratif Kecamatan Baturraden Kabupaten Banyumas merupakan daerah pegunungan yang secara otomatis memiliki dataran yang tinggi, serta letaknya yang relatif jauh dari pusat Pemerintahan Kabupaten sehingga data informasi melalui analisis SIG (Sistem Informasi Geografis) mutlak dibutuhkan. Kondisi aksesibilitas di sebagian daerah di Kecamatan tersebut relatif sulit dijangkau dan membawa dampak 
dalam memenuhi kelengkapan sarana dan prasarana perpustakaan Sekolah Dasar. Peta melalui analisis spasial dengan SIG (Sistem Informasi Geografis) dengan informasi yang terkandung di dalamnya mampu memberikan gambaran terkait hal tersebut di atas, Sehingga di masa yang mendatang tidak lagi ditemui kondisi sarana dan prasarana perpustakaan yang belum memadai dan tidak sesuai dengan standar yang telah ditetapkan oleh pemerintah.

\section{METODE PENELITIAN}

Penelitian ini merupakan penelitian deskriptif kualitatif dengan pendekatan keruangan yang merupakan salah satu pendekatan dalam geografi, penelitian ini akan mengungkap fenomena yang terjadi mengenai persebaran Sekolah Dasar dan kondisi sarana dan prasarana Sekolah Dasar. Subyek dalam penelitian adalah Sekolah Dasar dan pengelola perpustakaan atau guru yang dianggap dapat memberikan informasi secara detail tentang kondisi sarana dan prasarana perpustakaan sekolah, dengan demikian penentuan nara sumber menggunakan model snow ball sampling hal ini dilakukan untuk mendapatkan data dan informasi yang memuaskan. Penentuan sampel sekolah dengan purposif sampling. Sumber data adalah data primer dan sekunder. Teknik pengumpulan data wawancara, observasi dan dokumentasi.

Karena penelitian ini bersifat kualitatif, maka penelitian ini menggunakan analisis interaktif dengan sedikit perubahan mulai dari tahap pengumpulan data, analisis data dengan SIG, reduksi data, sajian data dan penarikan simpulan atau verifikasi.

Analisis kondisi sarana dan prasarana perpustakaan Sekolah Dasar dideskripsikan dengan melihat kesesuaiannya dengan standar sarana dan prasarana perpustakaan yang tertuang dalam Peraturan Menteri Pendidikan 
Dhi Bramasta dan Dedy Irawan : Persebaran Sarana dan Prasarana Perpustakaan Sekolah Dasar Berbasis Sistem Informasi Geografis

Nasional RI Nomor 24 Tahun 2007tentang Standar Sarana dan Prasarana Sekolah/madrasah Pendidikan Umum. Pada Bab II Tentang Standar Sarana dan Prasarana SD/MI seperti terlihat pada tabel 1 berikut :

Tabel 1. Jenis, Rasio dan Deskripsi Sarana Ruang Perpustakaan

\begin{tabular}{|c|c|c|c|}
\hline No & Jenis & Rasio & Deskripsi \\
\hline 1 & Buku & & \\
\hline 1.1 & $\begin{array}{ll}\text { Buku } & \text { teks } \\
\text { pelajaran } & \end{array}$ & $\begin{array}{l}1 \text { eksemplar/ mata } \\
\text { pelajaran/ peserta didik, } \\
\text { ditambah } 2 \\
\text { eksemplar/mata } \\
\text { pelajaran/sekolah }\end{array}$ & $\begin{array}{l}\text { termasuk dalam daftar buku teks } \\
\text { pelajaran yang ditetapkan oleh } \\
\text { Mendiknas dan daftar buku teks } \\
\text { muatan lokal yang ditetapkan oleh } \\
\text { Gubernur atau Bupati/Walikota }\end{array}$ \\
\hline 1.2 & $\begin{array}{l}\text { Buku Panduan } \\
\text { pendidikan }\end{array}$ & $\begin{array}{l}1 \text { eksemplar/ mata } \\
\text { pelajaran/ guru mata } \\
\text { pelajaran bersangkutan } \\
\text { ditambah } 1 \text { eksemplar/ } \\
\text { mata pelajaran/sekolah }\end{array}$ & \\
\hline 1.3 & $\begin{array}{l}\text { Buku } \\
\text { pengayaan }\end{array}$ & 840 judul/sekolah & $\begin{array}{l}\text { terdiri dari } 60 \% \text { non fiksi dan } 40 \% \\
\text { fiksi. Banyak eksemplar/sekolah } \\
\text { minimum } 1000 \text { untuk } 6 \text { rombongan } \\
\text { belajar, } 1500 \text { untuk } 7-12 \text { rombongan } \\
\text { belajar, } 2000 \text { untuk } 13-24 \\
\text { rombongan belajar }\end{array}$ \\
\hline 1.4 & Buku referensi & 10 judul/sekolah & $\begin{array}{l}\text { sekurang-kurangnya meliputi } \\
\text { Kamus Besar Bahasa Indonesia, } \\
\text { Kamus Bahasa Inggris, ensiklopedi, } \\
\text { buku statistik daerah, buku telepon, } \\
\text { kitab undang-undang dan peraturan } \\
\text { dan kitab suci }\end{array}$ \\
\hline 1.5 & $\begin{array}{l}\text { Sumber belajar } \\
\text { lain }\end{array}$ & $10 \mathrm{judul} / \mathrm{sekolah}$ & $\begin{array}{l}\text { Sekurang-kurangnya meliputi } \\
\text { majalah,, surat kabar, globe, peta, } \\
\text { gambar pahlawan nasional, CD } \\
\text { pembelajaran, dan alat peraga } \\
\text { matematika }\end{array}$ \\
\hline 2 & Perabot & & \\
\hline 2.1 & Rak buku & $1 \mathrm{set} /$ sekolah & $\begin{array}{l}\text { Kuat, stabil dan aman. Dapat } \\
\text { menampung seluruh koleksi dengan } \\
\text { baik. Memungkinkan peserta didik } \\
\text { menjangkau koleksi buku dengan } \\
\text { mudah. }\end{array}$ \\
\hline 2.2 & Rak Majalah & $1 \mathrm{buah} /$ sekolah & $\begin{array}{l}\text { Kuat, stabil dan aman. Dapat } \\
\text { menampung seluruh koleksi dengan } \\
\text { baik. Memungkinkan peserta didik } \\
\text { menjangkau koleksi majalah dengan } \\
\text { mudah. }\end{array}$ \\
\hline
\end{tabular}




\begin{tabular}{|c|c|c|c|}
\hline 2.3 & Rak surat kabar & 1 buah/sekolah & $\begin{array}{l}\text { Kuat, stabil dan aman. Dapat } \\
\text { menampung seluruh koleksi dengan } \\
\text { baik. Memungkinkan peserta didik } \\
\text { menjangkau koleksi surat kabar } \\
\text { dengan mudah. }\end{array}$ \\
\hline 2.4 & Meja baca & $10 \mathrm{buah} / \mathrm{sekolah}$ & $\begin{array}{l}\text { kuat, stabil, aman dan mudah } \\
\text { dipindahkan oleh peserta didik. } \\
\text { Desain memungkinkan kaki peserta } \\
\text { didik masuk dengan leluasa ke } \\
\text { bawah meja. }\end{array}$ \\
\hline 2.5 & Kursi Baca & $10 \mathrm{buah} / \mathrm{sekolah}$ & $\begin{array}{l}\text { Kuat, stabil, aman dan mudah } \\
\text { dipindahkan oleh peserta didik. } \\
\text { Desain dudukan dan sandaran } \\
\text { membuat peserta didik nyaman } \\
\text { belajar. }\end{array}$ \\
\hline 2.6 & Kursi kerja & $1 \mathrm{buah} /$ petugas & $\begin{array}{l}\text { Kuat, stabil, aman. Ukuran yang } \\
\text { memadai untuk bekerja dengan } \\
\text { nyaman. }\end{array}$ \\
\hline 2.7 & $\begin{array}{l}\text { Meja } \\
\text { kerja/sirkulasi }\end{array}$ & $1 \mathrm{buah} /$ petugas & $\begin{array}{l}\text { Kuat, stabil, aman. Ukuran yang } \\
\text { memadai untuk bekerja dengan } \\
\text { nyaman. }\end{array}$ \\
\hline 2.8 & Lemari katalog & $1 \mathrm{buah} /$ sekolah & $\begin{array}{l}\text { Cukup untuk menyimpankartu-kartu } \\
\text { katalog. Lemari katalog dapat } \\
\text { diganti dengan meja untuk } \\
\text { menempatkan katalog. }\end{array}$ \\
\hline 2.9 & Lemari & $1 \mathrm{buah} / \mathrm{sekolah}$ & $\begin{array}{l}\text { Kuat, stabil, aman. Ukuran } \\
\text { memadai untuk menampung seluruh } \\
\text { peralatan untuk pengelolaan } \\
\text { perpustakaan, dapat dikunci. }\end{array}$ \\
\hline 2.10 & $\begin{array}{l}\text { Papan } \\
\text { pengumuman }\end{array}$ & $1 \mathrm{buah} / \mathrm{sekolah}$ & ukuran minimum $1 \mathrm{~m}^{2}$ \\
\hline 2.11 & $\begin{array}{l}\text { Meja } \\
\text { multimedia }\end{array}$ & $1 \mathrm{buah} /$ sekolah & $\begin{array}{l}\text { Kuat, stabil dan aman. Ukuran } \\
\text { memadai untuk menampung seluruh } \\
\text { peralatan multimedia. }\end{array}$ \\
\hline 3 & $\begin{array}{l}\text { Media } \\
\text { Pendidikan } \\
\end{array}$ & & \\
\hline 3.1 & $\begin{array}{l}\text { Peralatan } \\
\text { multimedia }\end{array}$ & $1 \mathrm{set} / \mathrm{sekolah}$ & $\begin{array}{l}\text { Sekurang-kurangnya terdiri dari } 1 \\
\text { set komputer (CPU, monitor } \\
\text { minimum } 15 \text { inci, printer) TV, radio } \\
\text { dan pemutar VCD/DVD. }\end{array}$ \\
\hline 4 & $\begin{array}{l}\text { Perlengkapan } \\
\text { Lain }\end{array}$ & & \\
\hline 4.1 & Buku Inventaris & $1 \mathrm{buah} /$ sekolah & \\
\hline 4.2 & Tempat sampah & 1 buah/ruang & \\
\hline 4.3 & Kotak-kotak & $1 \mathrm{buah} / \mathrm{ruang}$ & \\
\hline 4.4 & Jam dinding & 1 buah/ruang & \\
\hline
\end{tabular}

Sumber : LampiranPeraturan Menteri Pendidikan Nasional RI Nomor 24 Tahun 2007 Bab II 
Dengan melihat standar sarana dan prasarana perpustakaan seperti pada tabel 1 tersebut, maka dapat diketahui sesuai dan tidaknya kondisi perpustakaan Sekolah Dasar tersebut.

Untuk menjelaskan persebaran atau distribusi Sekolah Dasar di Kecamatan menggunakan analisis tetangga terdekat (nearestneighbour analysis) dengan aplikasi SIG dengan software Arcgis 10.1. Sehingga diketahui pola persebarannya apakah mengikuti pola random, mengelompok atau seragam, yang ditunjukkan dari besarnya nilai T. Hasil analisis inimemberikan gambaran terhadap kecenderungan mengapa menunjukkan kecenderungan pada suatu pola tertentu, dikaitkan dengan analisis faktor yang mempengaruhinya.

Nilai T/indeks penyebaran tetangga terdekat sendiri diperoleh melalui formula :

$$
\mathrm{T}=\frac{j_{u}}{j_{h}}
$$

Dimana :

$\mathrm{T} \quad$ : indeks penyebaran tetangga terdekat

$j_{u} \quad$ : jarak rata-rata yang diukur antara satu titik dengan titik tetangganya yang terdekat

$j_{h} \quad$ : jarak rata-rata yang diperoleh andaikata semua titik mempunyai pola random $=\frac{1}{2 \sqrt{p}}$

$\mathrm{P} \quad$ : kepadatan titik dalam tiap kilometer per segi yaitu jumlah titik (N) dibagi luas wilayah $(\mathrm{A})$

Dari nilai $\mathrm{T}$, selanjutnya diinterpretasikan dengan Continum Nearest Neighbour Analysis, sebagai berikut : 


\section{Gambar 1. Analisis Tetangga Terdekat (Nearest Neighbour Analysis)}

$$
\mathrm{T}=0 \quad \mathrm{~T}=1,0 \quad \mathrm{~T}=2,15
$$

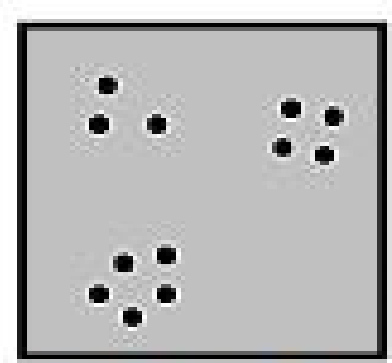

Mengelompor $T=0$

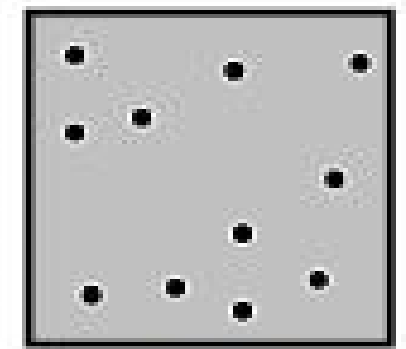

Fandor: $T-1,00$

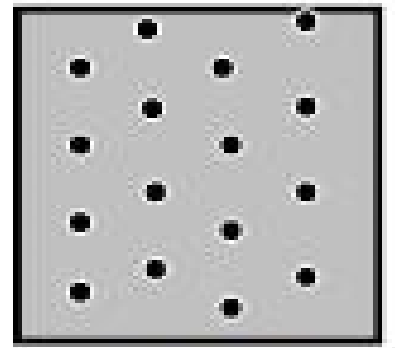

Seragam $T-2,15$

Sumber : Hagget dalam Bintarto dan Hadisumarno (1982 : 76)

\section{HASIL DAN PEMBAHASAN}

\section{A. Letak, Luas dan Batas}

Kemudahan teknologi komputer saat ini memberikan implikasi pada perkembangan teknologi pemetaan dan sistem informasi geografis. Beberapa negara telah memanfaatkan teknologi ini dan mengintegrasikannya dengan berbagai kebutuhan. Peran sistem informasi geografis ini bahkan telah berkembang pesat hingga industri dan informasi yang bersifat partisipatif dari berbagai stakeholder dapat dengan mudah diakses publik. Kemudahan dalam melakukan modifikasi dan manipulasi dalam analisis di lingkungan sistem informasi geografis tentu saja memberikan keuntungan khususnya bagi para pengguna termasuk pemerintah untuk melihat ruang dan secara praktis melakukan analisis terhadap kebutuhan pengguna dan masyarakat.

Kecamatan Baturraden merupakan salah satu Kecamatan yang berada $\pm 7 \mathrm{Km}$ arah utara Kota Purwokerto (Ibu Kota Kabupaten Banyumas). 
Secara geografis sebagian wilayahnya berupa hamparan dan sebagian lainnya berupa pegunungan (Statistik Kecamatan Baturraden, 2016).

Berdasarkan data BPS Kecamatan Baturraden Kabupaten Banyumas tahun 2016, Kecamatan Baturraden mempunyai batas wilayah sebagai berikut :

1. Sebelah utara : Kabupaten Purbalingga

2. Sebelah selatan : Kecamatan Purwokerto Utara

3. Sebelah barat : KecamatanKedungbanteng

4. Sebelah timur : Kecamatan Sumbang

Batas-batas wilayah Kecamatan Baturraden dapat dilihat pada Peta 1berikut : 


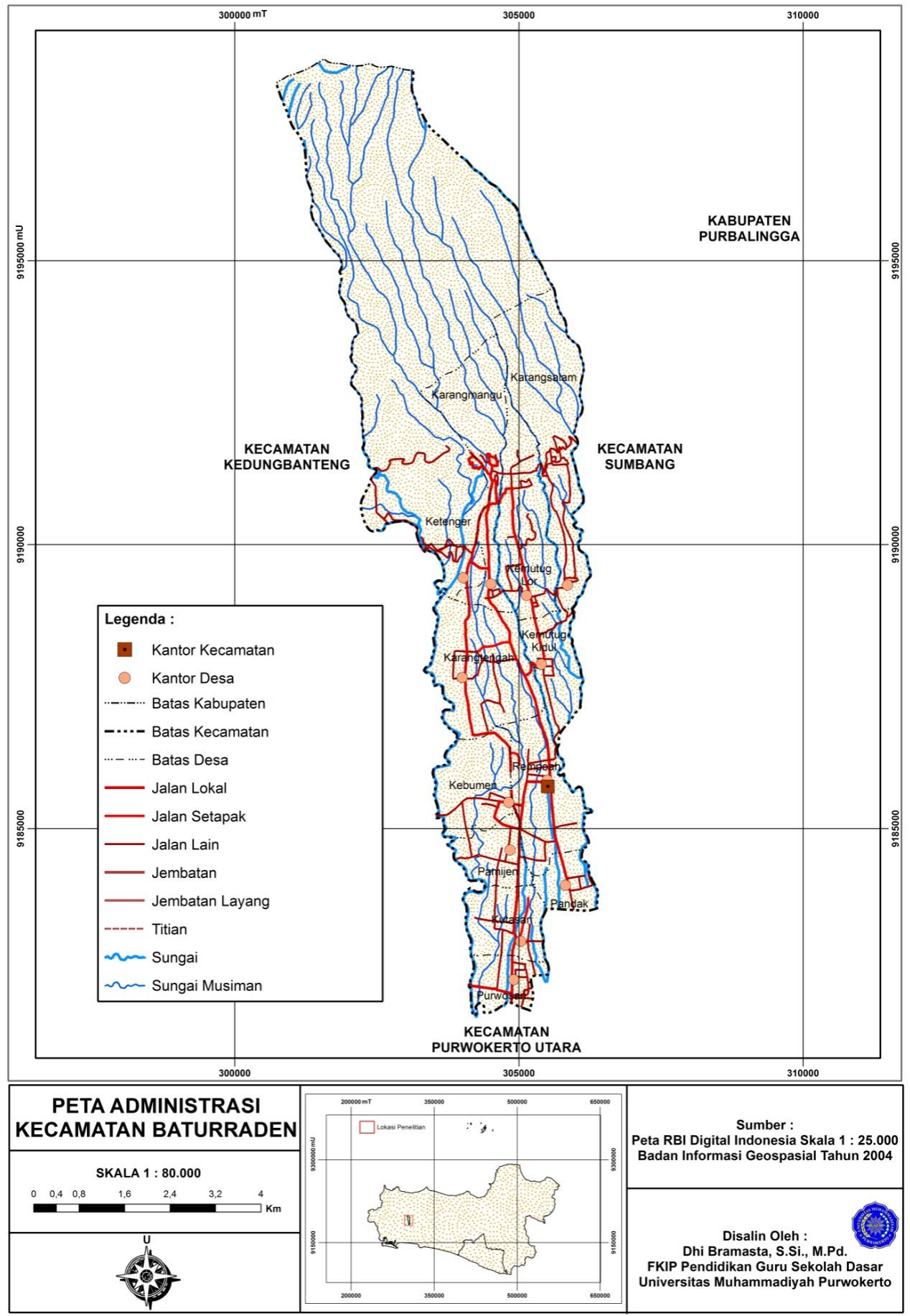


Dhi Bramasta dan Dedy Irawan : Persebaran Sarana dan Prasarana Perpustakaan Sekolah Dasar Berbasis Sistem Informasi Geografis

Luas wilayah Kecamatan Baturraden $45,53 \mathrm{Km}^{2}$, berdasarkan data monografi Kecamatan Baturraden, terdapat 20,75 \% merupakan lahan pertanian berupa lahan sawah serta lebih dari $50 \%$ merupakan hutan negara seluas $\pm 2.551,2 \mathrm{Ha}$.

Kecamatan Baturraden terdiri dari12 Desa yaitu Desa Purwosari, Desa Kutasari, Desa Pandak, Desa Pamijen, Desa Rempoah, Desa Kebumen, Desa Karangtengah, Desa Kemutug Kidul, Desa Karangsalam, Desa Kemutug Lor, Desa Karangmangu, Desa Ketenger (Statistik Baturraden 2016).

\section{B. Komposisi Penduduk Menurut Mata Pencaharian}

Mata pencaharian penduduk Kecamatan Baturraden bervariasi dapat disebutkan antara lain dalam bidang pertanian, pertambangan dan penggalian, industri, listrik dan gas serta air, konstruksi, perdagangan, angkutan dan komunikasi, jasa dan lembaga keuangan. Kemudian data jumlah penduduk Kecamatan Baturraden menurut mata pencaharian tiap Desa disajikan pada tabel komposisi penduduk menurut mata penaharian Kecamatan Baturaden berikut :

\section{Tabel2.Komposisi Penduduk 15 Tahun Ke Atas Menurut Lapangan Pekerjaan Kecamatan Baturraden Tahun 2013}

\begin{tabular}{|c|l|c|c|c|c|c|c|c|c|c|c|}
\hline No & Desa & $\begin{array}{c}\text { Perta- } \\
\text { nian }\end{array}$ & $\begin{array}{c}\text { Pertam- } \\
\text { bangan } \\
\text { dan } \\
\text { Penggalian }\end{array}$ & Industri & $\begin{array}{c}\text { Listrik, } \\
\text { Gas dan } \\
\text { Air }\end{array}$ & $\begin{array}{c}\text { Konstru } \\
\text { ksi }\end{array}$ & $\begin{array}{c}\text { Perda- } \\
\text { gangan }\end{array}$ & $\begin{array}{c}\text { Angkutan } \\
\text { dan } \\
\text { Komunikasi }\end{array}$ & $\begin{array}{c}\text { Lem- } \\
\text { baga } \\
\text { Keuan } \\
\text { gan }\end{array}$ & Jasa & Jumlah \\
\hline $\mathbf{( 1 )}$ & \multicolumn{1}{|c|}{ (2) } & $(\mathbf{3})$ & $(\mathbf{4})$ & $\mathbf{( 5 )}$ & $\mathbf{6})$ & $\mathbf{( 7 )}$ & $\mathbf{( 8 )}$ & $\mathbf{( 9 )}$ & $\mathbf{( 1 0 )}$ & $(\mathbf{1 1})$ & $(\mathbf{1 2})$ \\
\hline 1 & Purwosari & 4441 & 12 & 171 & 78 & 502 & 1.545 & 247 & 252 & 1.322 & 4.570 \\
\hline 2 & Kutasari & 630 & 7 & 147 & 38 & 678 & 1.135 & 207 & 75 & 1.171 & 4.088 \\
\hline 3 & Pandak & 364 & 10 & 70 & 37 & 289 & 473 & 122 & 40 & 420 & 1.825 \\
\hline 4 & Pamijen & 355 & 2 & 74 & 23 & 253 & 612 & 74 & 34 & 417 & 1.844 \\
\hline 5 & Rempoah & 1.146 & 20 & 361 & 96 & 547 & 1.890 & 265 & 49 & 1.165 & 5.539 \\
\hline 6 & Kebumen & 758 & 6 & 108 & 10 & 122 & 713 & 120 & 29 & 401 & 2.267 \\
\hline 7 & Karangtengah & 1.301 & 2 & 446 & 44 & 796 & 1.591 & 170 & 24 & 585 & 4.959 \\
\hline 8 & Kemutug Kidul & 667 & 2 & 408 & 9 & 94 & 518 & 92 & 9 & 278 & 2.077 \\
\hline 9 & Karangsalam & 652 & 4 & 22 & 12 & 325 & 357 & 28 & 20 & 229 & 1.649 \\
\hline 10 & Kemutug Lor & 1.012 & 12 & 139 & 19 & 373 & 1.270 & 112 & 41 & 505 & 3.483 \\
\hline 11 & Karangmangu & 325 & 9 & 68 & 45 & 150 & 1.320 & 119 & 41 & 777 & 2.854 \\
\hline 12 & Ketenger & 691 & 3 & 70 & 65 & 195 & 700 & 100 & 25 & 533 & 2.382 \\
\hline
\end{tabular}

Sumber : Badan Pusat Statistik Kabupaten BanyumasTahun 2014 
Tabel 2 di atas menujukkan bahwa mata pencaharian penduduk Kecamatan Baturraden paling besar pada sektor perdagangan yaitu 12.124 orang. Hal ini disebabkan Kecamatan Baturraden merupakan daerah pariwisata yang banyak dikunjungi oleh wisatawan lokal maupun manca negara, sehingga secara tidak langsung membuka lapangan pekerjaan tersendiri bagi penduduk sekitar yaitu dalam bidang perdagangan. Jenis barang yang diperjualbelikan seperti pakaian, makanan, cinderamata dan masih banyak lagi sehingga membawa keuntungan tersendiri bagi penduduk dalam memenuhi kebutuhan hidupnya.

Mata pencaharian yang mempunyai jumlah terendah pada sektor pertambangan dan penggalian yaitu 89 orang. Karena Baturraden merupakan daerah pegunungan, jjka kegiatan pertambangan dan penggalian dilakukan di daerah ini maka akan banyak mengakibatkan dampak yang negatif, misalnya tanah longsor, pemandangan alam pengungungan Bturraden menjadi rusak. Sehingga kegiatan pertambangan dan penggalian tidak berkembang di daerah ini.

\section{Penggunaan Lahan}

Penggunaan lahan di Kecamatan Baturraden didominasi oleh hutan negara. Perbandingan penggunaan lahan daerah penelitian dapat dipergunakan untuk mengetahui perubahan dan perkembangan penggunaan lahan dalam kurun waktu tertentu, perbandingan penggunaan lahan daerah penelitian periode tahun 2013, 2014 dan 2015 disajikan pada Tabel 3 di bawah ini : 
Dhi Bramasta dan Dedy Irawan : Persebaran Sarana dan Prasarana Perpustakaan Sekolah Dasar Berbasis Sistem Informasi Geografis

\section{Tabel 3. Perubahan Luas Penggunaan Lahan Kecamatan BaturradenKabupaten}

Banyumas Tahun 2014, 2015 dan 2016

\begin{tabular}{|c|c|c|c|c|c|}
\hline No & Pengunaan Lahan & 2013 & 2014 & 2015 & Jumlah \\
\hline 1. & Pengairan Teknis (Ha) & - & - & - & - \\
\hline 2. & $\begin{array}{lll}\begin{array}{l}\text { Pengairan } \\
\text { (Ha) }\end{array} & 1 / 2 & \text { Teknis } \\
\end{array}$ & 944,91 & 944,91 & 944,91 & $283,473.00$ \\
\hline 3. & $\begin{array}{l}\text { Pengairan Sederhana } \\
(\mathrm{Ha})\end{array}$ & - & - & - & - \\
\hline 4. & Tadah Hujan $(\mathrm{Ha})$ & - & - & - & - \\
\hline 5. & Tanah Kering (Ha) & - & - & - & - \\
\hline 6. & $\begin{array}{l}\text { Pekarangan/Bangunan } \\
\text { (Ha) }\end{array}$ & 412,27 & 412,27 & 412,27 & $123,681.00$ \\
\hline 7. & Tegal/Kebun $(\mathrm{Ha})$ & 496,19 & 496,19 & 496,19 & $148,857.00$ \\
\hline 8. & Padang Gembala (Ha) & - & - & - & - \\
\hline 9. & Kolam $(\mathrm{Ha})$ & 13,96 & 13,96 & 13,96 & $4,188.00$ \\
\hline 10. & Hutan Negara $(\mathrm{Ha})$ & $2,551,20$ & $2,551,20$ & $2,551,20$ & $765,360.00$ \\
\hline 11. & $\begin{array}{ll}\text { Perkebunan } \\
(\mathrm{Ha})\end{array}$ & 5,00 & 5,00 & 5,00 & $1,500.00$ \\
\hline 12. & Lain-lain $(\mathrm{Ha})$ & 129,48 & 129,48 & 129,48 & $38,844.00$ \\
\hline \multicolumn{2}{|c|}{ Luas Wilayah (Ha) } & $455,301.00$ & $455,301.00$ & $455,301.00$ & \\
\hline
\end{tabular}

Sumber : Kecamatan Baturraden dalam Angka 2014, 2015 dan 2016

Dari tabel di atas dapat diketahui bahwa perubahan luas penggunaan lahan di Kecamatan Baturraden pada umumnya tidak mengalami perubahan selama kurun waktu tahun 2013, 2014 dan 2015.

Sebagian besar lahan di Kecamatan Baturraden digunakan sebagai hutan negara dengan luas $2.551,20 \mathrm{Ha}$ atau sebesar $56,03 \%$ dari periode tahun 2013, 2014 dan 2015, hal ini karena Indonesia termasuk hotspot country yaitu negara yang memiliki tingkat paling tinggi tingkat keterancaman kepunahan keragaman hayatinya, sebab banyak kasus terjadi sepserti kebakaran hutan, penebangan hutan secara besar-besaran. Hal-hal tersebut yang menyebabkan Indonesia termasuk dalam hotspot country. Untuk menyelamatkan hutan termasuk keanekaragaman hayati yang ada maka berbagai upaya konservasi dilakukan seperti dengan adanya hutan lindung, taman nasional, membangun kebun raya. Kecamatan Baturraden 
secara geografis merupakan daerah pegunungan dan sebagian wilayahnya merupakan hamparan sehingga rasional jika sebagian besar wilayahnya merupakan hutan serta memiliki habitat yang unik. Selain hal tersebut Kecamatan Baturraden merupakan salah satu daerah yang menjadi sasaran pemerintah dalam usaha konservasi untuk menyelamatkan keanekaragaman hayati serta menjaga kerusakan hutan seperti dibangunnya kebun Raya Baturraden, maka dari sangat rasional jika sebagian besar penggunaan lahan Kecamatan Baturraden merupakan hutan negara.

Penggunaan lahan yang paling rendah adalah perkebunan dengan luas 5,00 $\mathrm{Ha}$ atau sebesar 0,11\% dari jumlah luas lahan keseluruhan 4.553,01 Ha. Hal ini dikarenakan sebagian besar penduduk Kecamatan Baturraden lebih berkecimpung pada sektor perdagangan, dimana Kecamatan Baturraden merupakan daerah pariwisata yang banyak dikunjungi wisatawan domestik maupun manca negara sehingga usaha perdagangan berkembang di daerah ini.

Banyaknya sumber-sumber air yang melimpah di daerah tersebut maka kebutuhan air untuk tanaman padi tercukupi, walaupun memiliki udara yang sejuk dan cocok untuk usaha perkebunan namun kenyataannya sektor pertanian jauh lebih besar dibandingkan sektor perkebunan.

\section{Jumlah dan Kepadatan Penduduk}

Untuk mengetahui kepadatan atau kerapatan rata-rata penduduk Kecamatan Baturraden dapat dilihat pada tabel 4 berikut : 
Dhi Bramasta dan Dedy Irawan : Persebaran Sarana dan Prasarana Perpustakaan Sekolah Dasar Berbasis Sistem Informasi Geografis

\section{Tabel 4. Jumlah dan Kepadatan Penduduk Kecamatan Baturraden Kabupaten Banyumas Tahun 2016}

\begin{tabular}{|c|c|c|c|c|c|c|}
\hline \multirow[b]{2}{*}{ No } & \multirow[b]{2}{*}{ Desa } & \multirow{2}{*}{$\begin{array}{c}\text { Luas } \\
\text { Wilayah } \\
\left(\mathrm{Km}^{2}\right)\end{array}$} & \multicolumn{3}{|c|}{ Jumlah Penduduk } & \multirow{2}{*}{$\begin{array}{l}\text { Kepadatan } \\
\text { Penduduk } \\
\left(\mathrm{Jiwa} / \mathrm{Km}^{2}\right)\end{array}$} \\
\hline & & & $\begin{array}{l}\text { Laki- } \\
\text { laki }\end{array}$ & Perempuan & Jumlah & \\
\hline 1 & Purwosari & 0,94 & 2.982 & 2.981 & 5.963 & $6.311,70$ \\
\hline 2 & Kutasari & 1,38 & 2.759 & 2.776 & 5.535 & $3.930,43$ \\
\hline 3 & Pandak & 0,87 & 1.279 & 1.234 & 2.513 & $2.855,17$ \\
\hline 4 & Pamijen & 0,86 & 1.283 & 1.234 & 2.517 & $2.890,70$ \\
\hline 5 & Rempoah & 2,46 & 3.805 & 3.751 & 7.556 & $3.024,39$ \\
\hline 6 & Kebumen & 2,30 & 1.543 & 1.593 & 3.136 & $1.332,17$ \\
\hline 7 & Karangtengah & 3,05 & 3.453 & 3.341 & 6.794 & $2.207,87$ \\
\hline 8 & $\begin{array}{l}\text { Kemutug } \\
\text { Kidul }\end{array}$ & 1,50 & 1.427 & 1.388 & 2.815 & $1.961,33$ \\
\hline 9 & Karangsalam & 5,10 & 1.178 & 1.234 & 2.412 & 457,84 \\
\hline 10 & Kemutug Lor & 12,51 & 2.394 & 2.416 & 4.810 & 376,34 \\
\hline 11 & Karangmangu & 3,35 & 1.587 & 2.005 & 3.592 & $1.067,16$ \\
\hline 12 & Ketenger & 11,21 & 1.588 & 1.593 & 3.181 & 280,91 \\
\hline & Jumlah & 45,53 & 25.278 & 25.546 & 50.824 & 1.116 \\
\hline
\end{tabular}

\section{Sumber : Kecamatan Baturraden dalam Angka 2016}

Tabel di atas, menunjukkan jumlah penduduk yang terbesar berada di Desa Rempoah dengan jumlah penduduk 7.556jiwa, sedangkan jumlah penduduk yang terkecil Desa Karangsalam dengan jumlah penduduk 2.412jiwa. Sedangkan Desa yang mempunyai jumlah penduduk menengah yaitu di Desa Kutasari dengan jumlah 2.535jiwa. Kemudian kepadatan penduduk Kecamatan Baturraden, angka kepadatan tertinggi adalah DesaPurwosari yaitu $6.311 \mathrm{jiwa} / \mathrm{Km}^{2}$. Sedangkan kepadatan penduduk yang terendah yaitu DesaKetenger yaitu $280,91 \mathrm{jiwa} / \mathrm{Km}^{2}$.

Kemudian kepadatan penduduk Kecamatan Baturraden yaitu jumlah penduduk dibandingkan dengan luas wilayah Kecamatan Baturraden. Berdasarkan hal tersebut di atas maka angka kepadatan rata-rata penduduk Kecamatan Baturraden berdasarkan data tahun 2016 adalah sebagai berikut 
$\frac{50.824}{45,53}=1.116 \mathrm{jiwa} / \mathrm{Km}^{2}$

Menurut Soekanto (1982), kepadatan penduduk suatu wilayah dikatakan rendah apabila kepadatannya kurang dari $500 \mathrm{jiwa} / \mathrm{Km}^{2}$, sedang 500 sampai $1000 \mathrm{jiwa} / \mathrm{Km}^{2}$, tinggi lebih dari $1000 \mathrm{jiwa} / \mathrm{Km}^{2}$.

Berdasarkan perhitungan kepadatan penduduk tersebut berarti setiap satu kilometer persegi Kecamatan Baturraden didiami penduduk sebesar $1.116 \mathrm{jiwa} / \mathrm{Km}^{2}$, angka kepadatan penduduk tersebut adalah tergolong tinggi, mengingat Kecamatan Baturraden merupakan daerah pegunungan. Walaupun daerah pegunungan Kecamatan Baturraden juga merupakan daerah yang memiliki pesona alam yang menarik, sehingga sangat signifikan jika banyak wisatawan yang berkunjung serta banyak penduduk yang bertempat tinggal di daerah tersebut.

\section{E. Komposisi Penduduk Menurut Pendidikan}

Komposisi penduduk menurut pendidikan Kecamatan Baturraden Kabupaten Banyumas disajikan pada tabel 5 berikut :

Tabel 5. Penduduk Kecamatan Baturraden Usia Lima Tahun Ke Atas

Menurut Pendidikan Tahun 2014

\begin{tabular}{|c|l|c|c|c|c|c|c|}
\hline No & Desa & $\begin{array}{c}\text { Tidak/Belum } \\
\text { Tamat SD }\end{array}$ & $\begin{array}{c}\text { Tamat } \\
\text { SD }\end{array}$ & $\begin{array}{c}\text { Tamat } \\
\text { SLTP }\end{array}$ & $\begin{array}{c}\text { Tamat } \\
\text { SLTA }\end{array}$ & $\begin{array}{c}\text { Tamat } \\
\text { Akademi/PT }\end{array}$ & Jumlah \\
\hline 1 & Purwosari & 1.148 & 1.335 & 734 & 1.305 & 948 & 5.470 \\
\hline 2 & Kutasari & 1.214 & 1.495 & 871 & 1.050 & 326 & 4.956 \\
\hline 3 & Pandak & 681 & 705 & 360 & 371 & 124 & 2.241 \\
\hline 4 & Pamijen & 518 & 805 & 467 & 387 & 99 & 2.276 \\
\hline 5 & Rempoah & 2.047 & 2.119 & 1.138 & 1.068 & 353 & 6.725 \\
\hline 6 & Kebumen & 991 & 954 & 378 & 367 & 88 & 2.778 \\
\hline 7 & Karangtengah & 1.848 & 2.891 & 803 & 461 & 63 & 6.066 \\
\hline 8 & Kemutug Kidul & 984 & 947 & 340 & 183 & 62 & 2.516 \\
\hline 9 & Karangsalam & 626 & 943 & 292 & 162 & 45 & 2.068 \\
\hline 10 & Kemutug Lor & 1.321 & 1.547 & 689 & 592 & 108 & 4.257 \\
\hline 11 & Karangmangu & 562 & 927 & 498 & 1.118 & 194 & 3.299 \\
\hline 12 & Ketenger & 786 & 968 & 461 & 520 & 124 & 2.859 \\
\hline & Jumlah & $\mathbf{1 2 . 7 2 6}$ & $\mathbf{1 5 . 6 3 6}$ & $\mathbf{7 . 0 3 1}$ & $\mathbf{7 . 5 8 4}$ & $\mathbf{2 . 5 3 4}$ & $\mathbf{4 5 . 5 1 1}$ \\
\hline
\end{tabular}

Sumber : Monografi Kecamatan Baturraden 2014 
Memperhatikan tabel di atas, Desa Purwosari potensi untuk penduduk usia 5 tahun ke atas dengan tamatan Akademi/PT yang cukup banyak yaitu 948 orang. Rata-rata tingkat pendidikan di wilayah Kecamatan Baturraden adalah tamatan SD, Desa Karangtengah mempunyai tamatan SD yang paling banyak yaitu 2.891 orang atau sekitar 6,35 \%. Sedangkan Desa yang memiliki tamatan SD terendah adalah Desa Pandak yaitu 705 orang atau $1,54 \%$.

\section{F. Kondisi Sosial Ekonomi Penduduk}

Kecamatan Baturraden merupakan bagian dari wilayah Kabupaten Banyumas, yang terletak dibagian utara Kabupaten Banyumas. Merupakan daerah dataran tinggi atau pegunungan sehingga memiliki hawa yang relaif sejuk. Karena daerah pegunungan dengan hawa yang sejuk serta ketersediaan airnya melimpah maka pertanian cukup berkembang di daerah ini. Udara yang sejuk yang bagus untuk usaha perkebunan juga, namun usaha perkebunan kurang begitu berkembang dibandingkan bidang pertanian, pertanian yang dikembangkan adalah pertanian dengan irigasi $1 \frac{1}{2}$ teknis. Karena banyak terdapat sumber air yang melimpah, sehingga menggunakan sistem irigasi $1 / 2$ teknis dengan membuat pintu-pintu pengatur air yang berguna mengairi lahan sawah.

Menurut data statistik Kecamatan Baturraden, data menunjukkan bahwa sekarang ini justru yang sektor perdagangan yang lebih mendominasi mata pencaharian penduduk. Hal ini realistis mengingat Baturraden merupakan kawasan wisata yang banyak dikunjungi oleh wisatawan lokal maupun manca, sehingga tidak heran jika banyak penduduk yang beralih profesi menjadi pedagang. Dari wisatawan yang berkunjung ke Baturraden tersebut timbul inisiatif penduduk untuk 
menawarkan berbagai barang yang bisa ditawarkan, seperti baju tetang keindahan alam baturraden, berbagai makanan khas Banyumas, cindera mata, bibit pohon perkebunan dan lain sebagainya. Dengan demikian secara tidak langsung membawa kesejahteraan sendiri terhadap kehidupan penduduk setempat dan sektor perdagangan tumbuh signifikan di daerah ini.

\section{G. Persebaran dan Pola Keruangan Sekolah Dasar}

Kecamatan Baturraden berada dibagian paling utara Kabupaten Banyumas. Kecamatan ini memiliki jarak cukup jauh dari pusat kota, walaupun memiliki jarak yang jauh dari pusat kota namun jumlah Sekolah Dasar di Kecamatan Baturraden cukup memadai, Sekolah Dasar Kecamatan Baturraden disajikan pada tabel 6 berikut :

Tabel 6. Sekolah Dasar Di Kecamatan Baturraden

\begin{tabular}{|c|l|c|l|}
\hline No & \multicolumn{1}{|c|}{ Sekolah } & No & \multicolumn{1}{|c|}{ Sekolah } \\
\hline 1 & SD N 1 Karangtengah & 13 & SDN 1 Pamijen \\
\hline 2 & SD N 1 Kemutug Kidul & 14 & SDN 1 Purwosari \\
\hline 3 & SD N 1 Kemutug Lor & 15 & SDN 2 Kemutug Kidul \\
\hline 4 & SD N 1 Ketenger & 16 & SDN 2 Kemutuglor \\
\hline 5 & SD N 1 Pandak & 17 & SDN 2 Ketenger \\
\hline 6 & SD N 2 Pandak & 18 & SDN 2 Pamijen \\
\hline 7 & SD N 1 Rempoah & 19 & SDN 3 Karangtengah \\
\hline 8 & SD N 2 Karangtengah & 20 & SDN 3 Kutasari \\
\hline 9 & SD N 1 Kutasari & 21 & SDN 4 Karangtengah \\
\hline 10 & SD N Kalipagu & 22 & SDN 4 Rempoah \\
\hline 11 & SD N Karangsalam & 23 & SDN Karangmangu \\
\hline 12 & SD N Kebumen & 24 & SDN Kecil Munggangsari \\
\hline
\end{tabular}

Sumber : Diknas Kabupaten Banyumas 2016

Dari tabel di atas dapat diketahui bahwa terdapat 24 Sekolah Dasar di Kecamatan Baturraden Kabupaten Banyumas. Persebaran tersebut merata di setiap Desa. Desa Purwosari terdapat 1 Sekolah Dasar, Desa Kutasari 
terdapat 2 Sekolah Dasar, Desa Pandak terdapat 2 Sekolah Dasar, Desa Pamijen terdapat 2 Sekolah Dasar, Desa Rempoah terdapat 2 Sekolah Dasar, Desa Kebumen terdapat 1 Sekolah Dasar, Desa Karangtengah terdapat 4 Sekolah Dasar, Desa Kemutug Kidul terdapat 2 Sekolah Dasar, Desa Karangsalam terdapat 1 Sekolah Dasar, Desa Kemutug Lor terdapat 2 Sekolah Dasar, Desa Karangmangu terdapat 1 Sekolah Dasar, Desa Ketenger terdapat 3 Sekolah Dasar . Artinya 8Desa terdapat lebih dari 1 Sekolah Dasar, untuk Desa yang lain hanya terdapat 1 Sekolah Dasar. Hal ini menunjukkan bahwasanya Kecamatan Baturraden Kabupaten Banyumas dalam hal kebutuhan pendidikan khususnya pendidikan dasar sudah mencukupi, dengan ditunjukkan terdapat minimal 1 Sekolah Dasar di setiap Desa.

Dalam mengetahui persebaran Sekolah Dasar di Kecamatan Baturraden dilakukan plotting titik koordinat dengan menggunakan GPS (Global Positioning System). Plotting titik koordinat seperti terlihat pada gambar 2berikut :

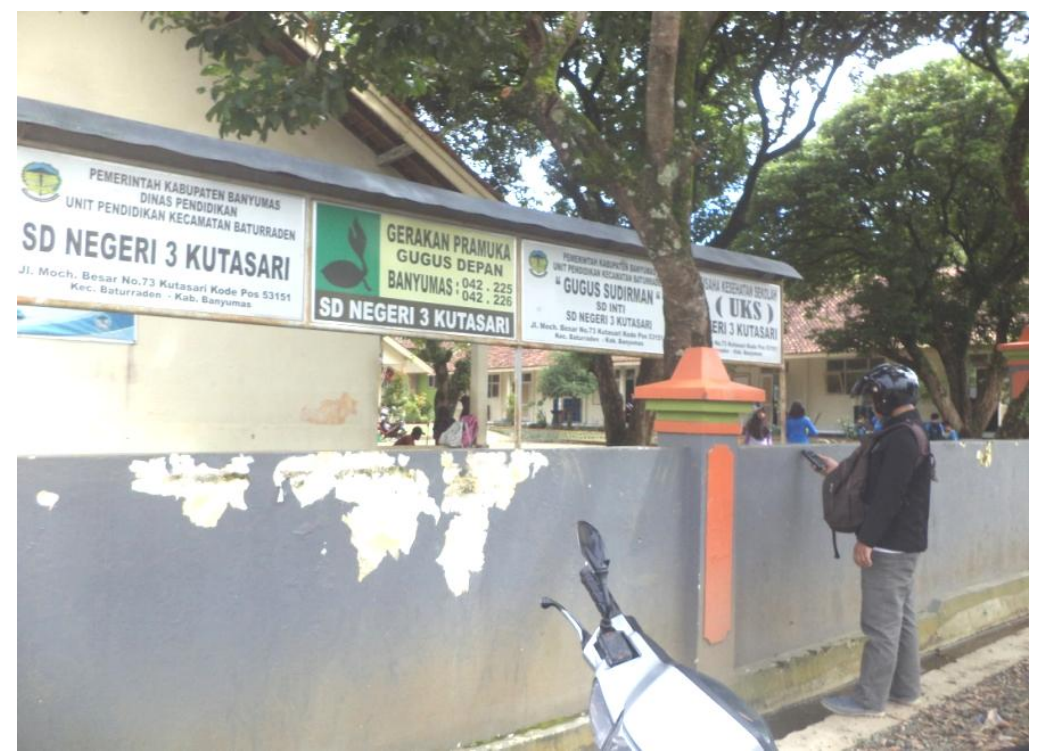

Gambar 2.Plotting Titik Lokasi di SDN 3 Kutasari 
Dengan Plotting titik koordinat sehingga didapatkan posisi letak sekolah tersebut secara pasti, sehingga diketahui pola persebaran dari sekolah tersebut.

Persebaran Sekolah Dasar Kecamatan Baturraden clustered/ mengelompok. Daerah yang paling banyak terdapat Sekolah Dasar adalah Desa Karangtengah, hal ini dikarenakan Desa Karangtengah merupakan salah satu desa yang berbatasan langsung dengan batas Kecamatan lain, serta memiliki jarak relatif dekat menuju ibukota Kecamatan Baturraden yaitu $\pm 3,5 \mathrm{Km}$. Secara aksesibilitas Desa Karangtengah baik dan mudah untuk dijangkau, jalan menuju daerah lain diluar wilayah Kecamatan Baturraden juga memadai serta didukung dengan jumlah penduduk terbesar ke dua di Kecamatan Baturraden setelah Desa Rempoah. Desa Karangtengah merupakan daerah yang memiliki kemiringan $25 \mathrm{~m}$ dengan ketinggian tempat antara 175 - $200 \mathrm{~m}$ dpal, tergolong dataran rendah, sehingga sangat signifikan jika Desa Karangtengah terdapat Sekolah Dasar paling banyak diantara desa-desa yang lain di Kecamatan Baturraden dengan memperhatikan hal-hal tersebut. Terdapat 4 Sekolah Dasar di Desa Karangtengah, sedangkan Desa yang lain rata-rata hanya terdapat 2 Sekolah Dasar. Persebaran Sekolah Dasar tersebut disajikan pada peta 2 berikut : 
Dhi Bramasta dan Dedy Irawan : Persebaran Sarana dan Prasarana Perpustakaan Sekolah Dasar Berbasis Sistem Informasi Geografis

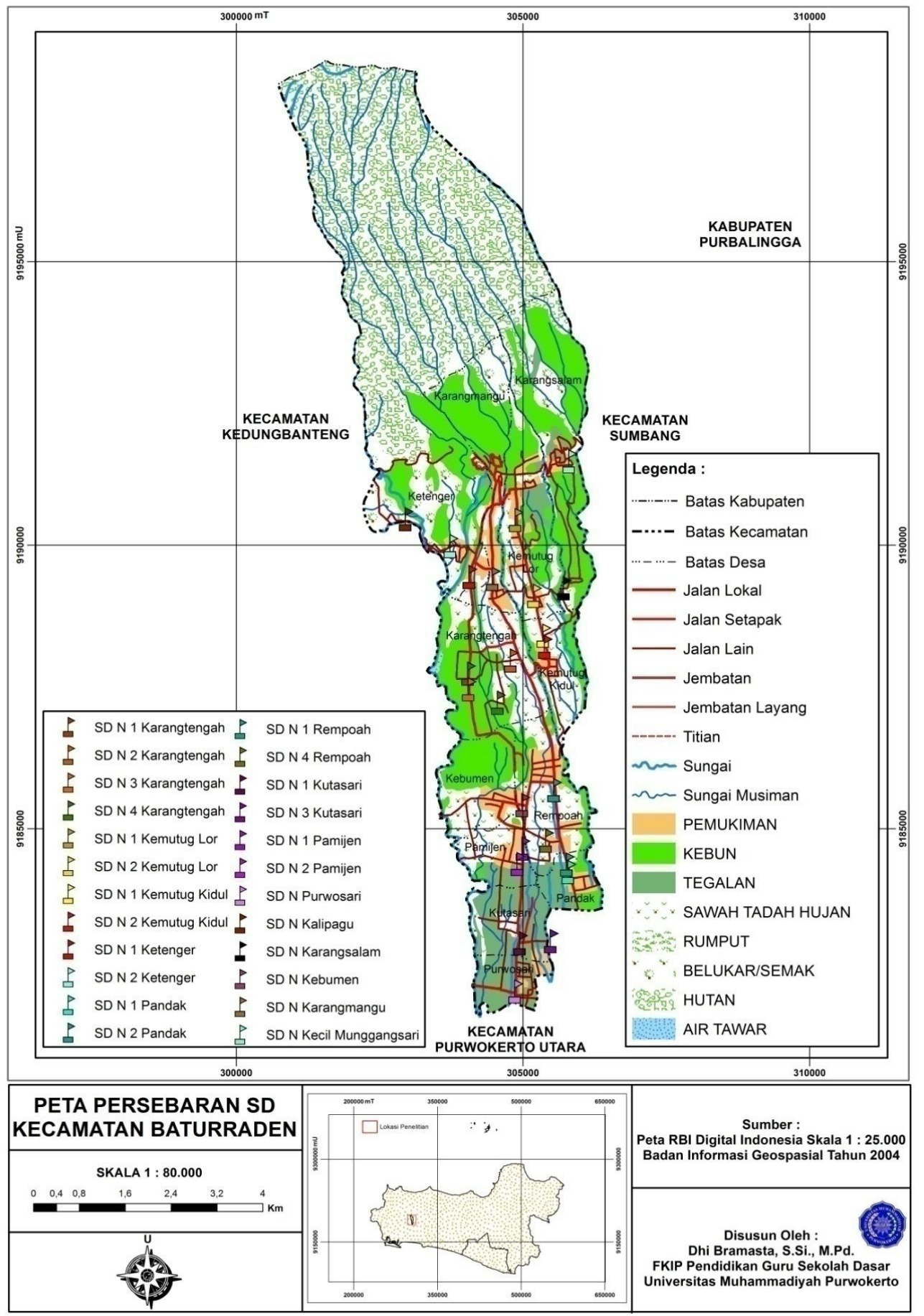


Sesuai dengan hasil analisis tetangga terdekat (nearest neighbour analysis) menggunakan aplikasi SIG, persebaran dan pola keruangan Sekolah Dasar Kecamatan Baturraden disajikan pada gambar 3berikut :

\title{
Gambar 3. Hasil Analisis Tetangga Terdekat
}

INearest Neighbour Analysis

Average Nearest Neighbor Summary

Nearest Neighbor Ratio: 0,000599

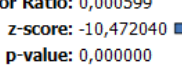

p-value: 0,000000
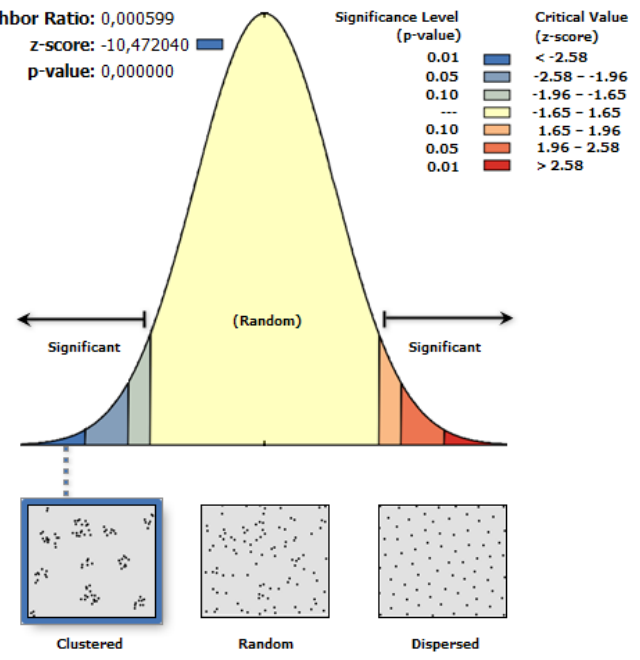

Average Nearest Neighbor Summary

Observed Mean Distance: 417,684269

Expected Mean Distance: 697330,886047

Nearest Neighbor Ratio: 0,000599

Z-score: $-10,472040$

p-value: 0,000000

\section{Dataset Information}

\author{
Input Feature Class: Lokasi_SD \\ Distance Method: EUCLIDEAN \\ Study Area: 58352443756280,852000
}

Sumber : Data Primer Tahun 2017 
Pola keruangan persebaran Sekolah Dasar Kecamatan Baturraden mengelompok mengikuti jalan atau jalur aksesibilitas. Hal ini disebabkan Kecamatan Baturraden merupakan daerah pegunungan yang memiliki dataran tinggi, sehingga di dalam membangun atau memilih lokasi dalam pendirian Sekolah Dasar dengan mempertimbangkan kemudahan sekolah tersebut untuk dijangkau, walaupun di beberapa daerah secara aksesibilitas sekolahnya relatif agak sulit dijangkau.

\section{H. Kondisi Sarana dan Prasarana Perpustakaan Sekolah Dasar}

Kondisi sarana dan prasarana perpustakaan sangat menunjang mutu pembelajaran yang dilaksanakan. Proses pembelajaran yang dilakukan dengan baik belum tentu bisa memberikan hasil yang maksimal tanpa didukung dengan sarana dan prasarana perpustakaan yang lengkap dan memadai sebagai sarana bagi siswa untuk menggali pengetahuan secara mandiri selain pengetahuan yang didapatkan di kelas. Jika kondisi sarana dan prasarana perpustakaan tidak sesuai dengan standar yang telah ditentukan oleh pemerintah yang dituangkan dalam Peraturan Menteri Pendidikan Nasional Nomor 24 Tahun 2007 Tanggal 28 Juni 2007 Tentang Standar Sarana Prasarana Sekolah/Madrasah Pendidikan Umum, salah satu yang termuat di dalamnya adalah standar sarana dan prasarana perpustakaan. Dengan demikian akan berakibat kurang maksimalnya kualitas pengetahuan yang didapatkan oleh siswa, karena tidak ditunjang oleh sarana dan prasarana perpustakaan yang kurang memadai.

Berikut merupakan keadaan perpustakaan Sekolah Dasar di Kecamatan Baturraden disajikan pada gambar berikut : 


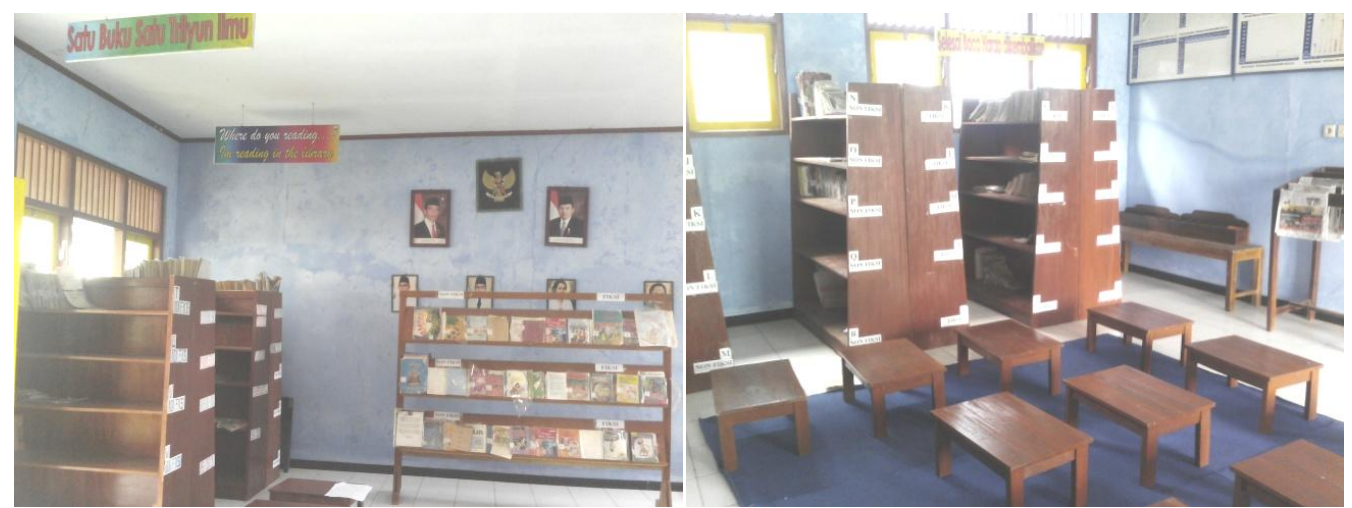

Gambar 4. Kondisi Perpustakaan Sekolah Dasar

Dari gambar 4 tersebut menunjukkan bahwasanya keadaan sarana dan prasarana perpustakaan masih sangat jauh dari standar yang ada, koleksi buku sangat minim serta perpustakaan kurang nyaman untuk melakukan aktifitas literasi dan aktifitas yang lain di perpustakaan.

Hal tersebut dapat diketahui dari jumlah buku dan peralatan yang ada di sekolah belum sesuai dengan mata pelajaran dan jumlah siswa yang ada di sekolah. Banyak faktor yang menyebabkan terjadinya ketidaksesuaian sarana dan prasarana perpustakaan di sekolah tersebut. Antara lain kebanyakan pihak sekolah dalam pengadaan buku baik buku pelajaran ataupun buku sumber belajar lain mengandalkan dana dari pemerintah dalam hal ini adalah dana BOS, sedangkan dana BOS sendiri dalam satu tahun dicairkan pemerintah secara bertahap yaitu setiap tri wulan (tri wulan I, II, III dan IV). Sedangkan dalam pengelolaan dana BOS pihak sekolah tidak hanya mengalokasikan untuk pengadaan buku saja, namun pihak sekolah lebih mengutamakan pengalokasian dana BOS tersebut ke dalam hal-hal yang lebih penting atau membutuhkan pendanaan dahulu, sehingga hal tersebut menghambat terpenuhinya berbagai 
kebutuhan perpustakaan termasuk buku dan peralatan perpustakaan yang lain.

Selain dana BOS, sekolah juga memiliki sumber dana yang lain antara lain yaitu dari SPP siswa dan dana bantuan yang lain. Namun kebanyakan dana-dana tersebut digunakan untuk pengembangan dan perawatan sekolah. Hal ini dilakukan dengan tujuan untuk memajukan kualitas sekolah supaya menjadi sekolah unggulan yang dapat diperhitungkan secara kualitas dan kuantitas. Sumber dana yang didapatkan sekolah seperti dana dari komite sekolah terkadang digunakan untuk menunjang kesejahteraan guru, khususnya untuk membayar gaji guru honorer. Bantuan buku dari pemerintah juga sudah banyak diterima oleh sekolah, namun pada kenyataannya jumlah buku yang tersedia di sekolah belum mampu memenuhi standar yang ditetapkan

Selanjutnya keadaan perabot perpustakaan seperti rak buku, rak majalah, meja kursi baca, meja multimedia, meja kursi sirkulasi dalam hal ini rata-rata Sekolah Dasar di Kecamatan Baturraden belum semua sekolah tersedia perlengkapan tersebut, walaupun di beberapa sekolah sudah lengkap namun masih banyak sekolah yang belum memiliki fasilitas perlengkapan tersebut. Fasilitas perabot atau perlengkapan yang banyak belum tersedia di sekolah antara lain kursi baca, lemari katalog, lemari untuk menampung peralatan perpustakaan dan meja multimedia. Hal ini disebabkan di beberapa sekolah memang sengaja tidak menggunakan kursi baca, sehingga siswa dalam membaca duduk di karpet. Kemudian terkait dengan minimnya dan perabot atau fasilitas yang dibutuhkan harganya mahal, seperti meja multimedia dan dalam penyediaannya jumlahnya juga harus memenuhi kebutuhan siswa sehingga belum mampu untuk 
mencapainya, karena membutuhkan dana yang cukup besar. Begitu juga dengan lemari katalog, lemari untuk menampung peralatan perpustakaan.

Kemudian terkait peralatan multimedia seperti komputer, TV, radio dan pemutar VCD/DVD rata Sekolah Dasar di Kecamatan Baturaden belum secara seluruhnya lengkap. Seperti komputer dan TV yang memiliki harga relatif mahal sehingga banyak sekolah yang belum memilikinya. Begitu juga dengan perlengkapan lain yang relatif sederhana tidak mahal jika dilihat dari harganya seperti jam dinding, kotak-kotak, buku inventaris, tempat sampah namun kenyataannya banyak sekolah yang belum menyediakan atau memilikinya. Hal ini disebabkan pengelolaan perpustakaan yang kurang maksimal, sehingga hal-hal sederhana tersebut tidak diperhatikan. Selain itu, belum semua sekolah memiliki pustakawan sehingga di dalam pengelolaan perpustakaan dan terkait dengan kebutuhan perpustakaan kurang diperhatikan, karena fokus pemikiran guru dan karyawan pada pembelajaran di kelas menjadikan perpustakaan kurang mendapat perhatian dari pihak sekolah.

Keadaan Sekolah Dasar di Kecamatan Baturraden rata-rata belum memiliki sarana dan prasarana yang memadai, sehingga dalam prosesnya banyak alokasi dana yang seharusnya bisa untuk melengkapi sarana dan prasarana perpustakaan justru dialokasikan untuk pengembangan sekolah. Secara geografis Kecamatan Baturraden merupakan daerah dataran tinggi, merupakan daerah pegunungan dan secara aksesibilitas di beberapa Sekolah Dasar sulit untuk dijangkau. Jarak Kecamatan dengan Ibu Kota Kabupaten juga jauh, sedangkan kebanyakan berbagai fasilitas berada di pusat kota, sehingga dalam kebutuhan untuk memenuhi kebutuhan yang diperlukan sekolah memerlukan perjalanan yang cukup jauh untuk mendapatkannya. Hal tersebut berpengaruh terhadap segala sarana dan 
Dhi Bramasta dan Dedy Irawan : Persebaran Sarana dan Prasarana Perpustakaan Sekolah Dasar Berbasis Sistem Informasi Geografis

prasarana yang ada di sekolah, termasuk sarana dan prasarana perpustakaan.

\section{KESIMPULAN}

1. Persebaran Sekolah Dasar Kecamatan Baturraden adalah clustered/ mengelompok dengan pola persebaran mengikuti jalan atau jalur aksesibilitas. Hal ini disebabkan Kecamatan Baturraden merupakan daerah pegunungan yang memiliki dataran tinggi, sehingga di dalam membangun atau memilih lokasi untuk mendirikan Sekolah Dasar dengan mempertimbangan kemudahan sekolah tersebut untuk dijangkau, walaupun dibeberapa daerah secara aksesibilitas sekolahnya relatif agak sulit dijangkau.

Terdapat 24 Sekolah Dasar di Kecamatan Baturraden, daerah yang paling banyak terdapat Sekolah Dasar adalah Desa Karangtengah, karena Desa Karangtengah merupakan salah satu desa yang berbatasan langsung dengan batas Kecamatan lain, serta memiliki jarak relatif dekat menuju ibukota Kecamatan Baturraden yaitu $\pm 3,5 \mathrm{Km}$. Secara aksesibilitas Desa Karangtengah baik dan mudah untuk dijangkau, didukung dengan jumlah penduduk terbesar ke dua di Kecamatan Baturraden setelah Desa Rempoah. Dengan demikian Kecamatan Baturraden Kabupaten Banyumas dalam hal kebutuhan pendidikan khususnya pendidikan dasar sudah mencukupi, dengan ditunjukkan terdapat minimal 1 Sekolah Dasar di setiap Desa.

2. Kondisi sarana dan prasarana perpustakaan Sekolah Dasar di Kecamatan Baturraden belum sesuai dengan standar yang ditetapkan oleh pemerintah yang tertuang dalam Peraturan Menteri Pendidikan Nasional Nomor 24 Tahun 2007 Tanggal 28 Juni 2007 Tentang Standar Sarana Prasarana Sekolah/Madrasah Pendidikan Umum. 
Jumlah buku dan peralatan yang ada di perpustakaan belum sesuai dengan mata pelajaran dan jumlah siswa yang ada di sekolah. Banyak faktor yang menyebabkan terjadinya ketidaksesuaian sarana dan prasarana perpustakaan di sekolah tersebut. Antara lain kebanyakkan pihak sekolah dalam pengadaan buku baik buku pelajaran ataupun buku sumber belajar lain mengandalkan dana bantuan dari pemerintah, sedangkan sumber dana yang lain digunakan untuk pengembangan sekolah seperti pembangunan gedung sekolah, perbaikan-perbaikan sekolah jika ada kerusakan.

\section{DAFTAR PUSTAKA}

Badan Pusat Statistik. 2014. Statistik Daerah Kecamatan Baturraden. Banyumas.

2015. Statistik Daerah Kecamatan Baturraden. Banyumas. 2016. Statistik Daerah Kecamatan Baturraden. Banyumas.

EncoMulyasa. 2005. Kurikulum Berbasis Kompetensi : Konsep, Karateristik, dan Impelemtasi. Bandung : Remaja Rosda Karya

R.Bintarto dan Hadisumarno. 1982. Metode Analisa Geografi. Jakarta: LP3ES.

Peraturan Menteri Pendidikan Nasional RI No. 24 Tahun 2007.Standar Sarana dan Prasarana Sekolah/Madrasah Pendidikan Umum.Depdiknas.

Soerjono Soekanto. 1982. Sosiologi Suatu Pengantar. Jakarta: Rajawali.

HB Sutopo. 1996. Metodelogi Penelitian Kualitatif, Metode Penelitian untuk IlmuSosial dan Budaya. Surakarta: UNSA Press. 